\title{
Preparation and Properties of Composite Materials with Magnesium Matrix and Hydroxy- apatite Reinforcement
}

Jiri Kubasek, Dalibor Vojtěch, Drahomir Dvorsky

Faculty of chemical technology, Department of Metals and Corrosion Engineering, UCT Prague, Technická 516628

Praha 6 - Dejvice, Czech Republic.E-mail: jiri.kubasek@ vscht.cz, vojtechd@ vscht.cz,dvorskyd@ vscht.cz

Magnesium materials seem perspective for application in the field of biodegradable implants. Such materials are gradually degraded, without the formation of toxic products in the organism. Different approaches have been performed to improve mechanical properties and corrosion resistance of magnesium based materials. Among them, preparation of composite materials with magnesium matrix and inorganic reinforcement is very attractive. Hydroxyapatite (HA) is considered as suitable reinforcement because it is included in human bones. Presence of HA in composite can support the process of osseointegration. The resulting properties of Mg-HA composites are affected by the amount and particle size of the $\mathrm{HA}$ as well as the actual process for the preparation of the composite. This paper deals with the preparation of composite materials of Mg-HA with different contents of $\mathrm{HA}$ reinforcement by suitable combination of powder metallurgy method (milling, pressing, extrusion and spark plasma sintering). The effect of these methods on final structure and mechanical properties was observed. All prepared composite materials were characterized by uniform distribution of reinforcement particles in the structure and slightly different mechanical properties based on HA content and preparation method.

Keywords: Magnesium, Composites, Hydroxyapatite, Mechanical properties

\section{Acknowledgement}

Authors wish to thank the Czech Science Foundation (project no. P108/12/G043) and specific university research (MSMT no. 20/2014) for the financial support of this research.

\section{References}

[1] WANG, X.; ZHANG, P.; DONG, L. H.; MA, X. L.; LI, J. T.; ZHENG, Y. F. (2014). Microstructure and characteristics of interpenetrating $\beta-\mathrm{TCP} / \mathrm{Mg}-\mathrm{Zn}-\mathrm{Mn}$ composite fabricated by suction casting. In: Materials \& Design, Vol. 54, No. 0, pp. 995-1001.

[2] FENG, A.; HAN, Y. (2011). Mechanical and in vitro degradation behavior of ultrafine calcium polyphosphate reinforced magnesium-alloy composites. In: Materials \& Design, Vol. 32, No. 5, pp. 2813-2820.

[3] YU, K.; CHEN, L.; ZHAO, J.; WANG, R.; DAI, Y.; HUANG, Q. (2013). In vivo biocompatibility and biodegradation of a $\mathrm{Mg}-15 \% \mathrm{Ca} 3(\mathrm{PO} 4) 2$ composite as an implant material. In: Materials Letters, Vol. 98, No. 0, pp. 22-25.

[4] WITTE, F.; FEYERABEND, F.; MAIER, P.; FISCHER, J.; STÖRMER, M.; BLAWERT, C.; DIETZEL, W.; HORT, N. (2007). Biodegradable magnesium-hydroxyapatite metal matrix composites. In: Biomaterials, Vol. 28, No. 13, pp. 2163-2174.

[5] THUAULT, A.; SAVARY, E.; HORNEZ, J. C.; MOREAU, G.; DESCAMPS, M.; MARINEL, S.; LERICHE, A. (2014). Improvement of the hydroxyapatite mechanical properties by direct microwave sintering in single mode cavity. In: Journal of the European Ceramic Society, Vol. 34, No. 7, pp. 1865-1871.

[6] GU, X.; ZHOU, W.; ZHENG, Y.; DONG, L.; XI, Y.; CHAI, D. (2010). Microstructure, mechanical property, biocorrosion and cytotoxicity evaluations of Mg/HA composites. In: Materials Science and Engineering: C, Vol. 30, No. 6, pp. 827-832.

[7] HAO, L.; LU, Y.; SATO, H.; ASANUMA, H.; GUO, J. (2013). Analysis on energy transfer during mechanical coating and ball milling-Supported by electric power measurement in planetary ball mill. In: International Journal of Mineral Processing, Vol. 121, No. 0, pp. 51-58.

[8] LARGILLER, G.; DONG, L.; BOUVARD, D.; CARRY, C. P.; GABRIEL, A. (2012). Deformation and cracking during sintering of bimaterial components processed from ceramic and metal powder mixes. Part II: Numerical simulation. In: Mechanics of Materials, Vol. 53, No. 0, pp. 132-141.

[9] TAVIGHI, K.; EMAMY, M.; EMAMI, A. R. (2013). Effects of extrusion temperature on the microstructure and tensile properties of Al-16wt\% Al4Sr metal matrix composite. In: Materials \& Design, Vol. 46, No. 0, pp. 598604.

[10]MUHAMMAD, W. N. A. W.; SAJURI, Z.; MUTOH, Y.; MIYASHITA, Y. (2011). Microstructure and mechanical properties of magnesium composites prepared by spark plasma sintering technology. In: Journal of Alloys and Compounds, Vol. 509, No. 20, pp. 6021-6029. 